\title{
Framework proposal for ecodesign integration on product portfolio management
}

\author{
Marco Antonio Paula Pinheiro a, Daniel Jugend ${ }^{a,}{ }^{*}$, Luiz Carlos Demattê Filho ${ }^{\mathrm{b}}$, \\ Fabiano Armellini ${ }^{\mathrm{c}}$ \\ a Sao Paulo State University - UNESP, Production Engineering Department, Av. Engenheiro Luiz Edmundo Carrijo Coube 14-01, PO BOX 17033-360, Bauru, \\ SP, Brazil \\ ${ }^{\mathrm{b}}$ Korin Company Ltd, Km 80,0 PO BOX 41 Zip Code 13 537000, Ipeuna, SP, Brazil \\ ${ }^{c}$ Department of Mathematics and Industrial Engineering, Polytechnique Montréal, 2900 Edouard Montpetit Blvd, Montreal, QC H3T 1J4, Canada
}

\section{A R T I C L E I N F O}

\section{Article history:}

Available online 2 March 2018

\section{Keywords:}

Ecodesign

Sustainable design

Product portfolio

Development of environmentally

sustainable products

Green product development

Green innovation

\begin{abstract}
A B S T R A C T
Although many studies on product portfolio management (PPM) and ecodesign exist, there are few investigations that analyze these areas in an integrated way. They are normally conceptually separated, with very few theoretical and empirical interactions evident in the literature. This article proposes a theoretical framework that integrates ecodesign practices, methods, and tools with portfolio management during the product planning stage. For the development of this framework, a systematic analysis and literature review of both PPM and ecodesign were conducted. The framework subsequently developed was evaluated through a pilot test within two companies that develop products derived from Brazilian biodiversity. In terms of results, it presents a set of practices that are associated with the following dimensions: Guides, Methods, and Tools; Organization; and Strategy. After presenting the evaluation of the framework by the companies, practices are proposed which can be useful for the integration of ecodesign into PPM, such as adoption of the Project Management Office (PMO) and the use of social media.
\end{abstract}

() 2018 Elsevier Ltd. All rights reserved.

\section{Introduction}

Patterns of production and consumption have undergone significant changes over recent decades (Smith and Offodile, 2016), not least with factors such as global climate change and biodiversity loss having become increasingly relevant, and the number of consumers concerned about these issues growing (Dangelico and Vocalelli, 2017; Ji et al., 2015). As a consequence, the development of practices and products that seek to minimize impacts on the environment has become increasingly prominent (Rossi et al., 2016).

Due to the importance of sustainable development, then, the consideration of environmental criteria from the stage of product portfolio management (PPM) may have a positive impact on the development of environmentally sustainable products. This is

\footnotetext{
* Corresponding author.

E-mail addresses: marco.pinheiro@faag.com.br (M.A. Paula Pinheiro), daniel@ feb.unesp.br (D. Jugend), luiz.dematte@korin.com.br (L.C. Demattê Filho), fabiano. armellini@polymtl.ca (F. Armellini).
}

particularly the case because late changes in new product development (NPD) projects can increase total costs and generate a greater impact on the environment (Boks, 2006; Jugend et al., 2017). Presenting a similar perspective, Cluzel et al. (2016) proposed a model for the generation and selection of eco-innovation project portfolios, suggesting the adoption of ecodesign at all stages, from the generation of ideas to the selection of projects to be developed.

PPM presents an opportunity to improve environmental impact in the NPD process, since it is at this moment that more possibilities for the choice of product characteristics exist, including the use of materials that consume less energy, products that use raw materials from fair trade, and so on (Bocken et al., 2014; Jugend et al., 2017; Ölundh and Titzén, 2004). In addition, PPM is relevant in terms of companies coherently deciding on their marketing strategies and, for instance, how green their product portfolio should be (Dangelico and Vocalelli, 2017). This is also a promising avenue for locating sustainability as a strategic axis for project selection and the prioritization of technological projects, which is a current challenge for the emerging fields of green innovation (Schiederig 
et al., 2016) and the circular economy (Sauvé et al., 2016).

At the same time, the literature has demonstrated the possibility of integrating ecodesign in industry, in order to guide and encourage product designers to apply principles of environmentally sustainable development (Brones et al., 2014; Eppinger, 2011; Pigosso et al., 2013; Sihvonen and Partanen, 2016). However, there are few studies that analyze these relationships more deeply. Therefore, some studies suggest the need to broaden research on ecodesign integration in the stages of product project selection (Brones and Carvalho, 2015; Brones et al., 2014; Carvalho and Rabechini Jr., 2017; Sihvonen and Partanen, 2016). For example, Carvalho and Rabechini Jr. (2017) indicate that the bridge between project management and sustainability is still being built, and that, in order to build this bridge, processes, tools, and techniques are needed. Studies such as Rossi et al. (2016) and Silvius et al. (2017) also suggest that there is a need to expand research that develops and proposes specific frameworks and guides that support managers in their decision-making activities in the selection of projects for environmentally sustainable products.

This study aims to contribute to this area by proposing a framework for the integration of ecodesign into PPM. In this context, we have formulated the following primary research question: How can product portfolio management be used for the effective introduction of ecodesign practices, methods, and tools?

Despite the apparent availability of studies suggesting the adoption of practices, methods, and tools for the application of ecodesign, other researchers have pointed out that its practical application is still incipient in companies (e.g., Dekoninck, et al., 2016; Rossi et al., 2016; Silvius et al., 2017). Some studies have proposed the adoption of sustainability in the initial stages of NPD process from different perspectives (e.g., Brook and Pagnanelli, 2014; Chang et al., 2013; Koga and Aoyama, 2008). Koga and Aoyama (2008) developed a method to design the optimal modular structure considering the life cycle of product family. Ölundh and Ritzén (2004) and Chang et al. (2013) suggested the application of methods such as stage-gates, green quality function deployment, and design structure matrix during the early product development stages. Taking a different perspective, our study proposes a framework with the tripartite dimensions of Guides, Methods, and Tools; Organization; and Strategy for the integration of ecodesign into PPM.

Initially, this theoretical framework was developed from a literature review. After that, the framework was evaluated by two companies with different levels of maturity in the application of ecodesign, and which develop products derived from Brazilian biodiversity. The concern for integrating ecodesign into PPM can be considered important, especially for firms developing products based on biodiversity, as they are companies involved in the development of products that directly impact species and ecosystems (Jabbour et al., 2018; Primmer et al., 2015). As such, the adoption of ecodesign can decrease the main causes of biodiversity loss, such as over-exploitation of natural resources, pollution, and soil contamination (Alvarado-Quesada et al., 2014).

The article is structured in five sections. Section 2 presents the theoretical concepts in PPM and ecodesign. Section 3 presents the research method used in this research. Section 4 proposes the theoretical framework and its subsequent evaluation by the companies. Section 5 discusses the results. Finally, Section 6 outlines our conclusions.

\section{Literature review}

\subsection{Product portfolio management}

Since the 1960s the discussion on how to allocate resources in new product and $R \& D$ projects has been studied by works in the area of innovation (Bitman and Sharif, 2008; Spieth and Lerch, 2014), NPD (Cooper et al., 1999; Kester et al., 2014), and project management (Archer and Ghasemzadeh, 1999; Killen, 2017). In general, PPM's role is to select, from a series of project options, those most in line with the firm's strategy (Kopmann et al., 2015), the prioritization, acceleration and discontinuity of the projects and also the optimal allocation of resources between them (Cooper et al., 1999).

It is also known that the good performance of a product portfolio is fundamentally aimed at achieving the following objectives: (i) strategic alignment: translate the company strategy into a set of products in order to consider the current and future product lines and determine which will be responsible for the viability of the innovation strategy (Cooper et al., 1999; Jugend et al., 2016; McNally et al., 2009); (ii) balance: the degree of innovation of the product projects that compose the portfolio (e.g., incremental and radical) and low risk/return projects (Cooper et al., 1999; Kester et al., 2014); (iii) maximized portfolio value: optimize the relationship between resources used and expected returns with product projects (e.g., Cooper et al., 1999; Kester et al., 2011); and (iv) preparing for future: benefits brought about by the new projects in the medium and long term for the creation of new markets, improved technologies, and to build new skills and competences to react to external challenges (Kock et al., 2015).

However, it is known that due to resource limitations and because they are related to the fuzzy front end of innovation (Brownin and Yassine, 2016), and occur in the planning phase of new product projects, decisions that relate to PPM can be difficult and complex (Cooper et al., 1999; Kester et al., 2011). Many companies fail at the strategic level because they generally focus on individual product projects and do not integrate them into other projects and strategic planning (e.g., Cooper et al., 1999; Jonas, 2010). Archer and Ghasemzadeh (1999) emphasize that if, on the one hand, companies have many projects, on the other hand, there is a limitation of time, financial and human resources for their adequate development, which hinders the optimal choice of projects.

Given the strategic role of PPM and the need to support managers to better manage this process, there are different practices suggested in the literature that are recommended for achieving adequate performance in the product portfolio. The applications of these practices can be useful for evaluating strategic, market, technological and risk factors, as well as the economic return of the product portfolio (Brownin and Yassine, 2016; Verbano and Nosella, 2010). Among these practices, we can exemplify the interfunctional integration (Perks, 2007) through the adoption of multifunctional teams (Kester et al., 2011) and project teams (Lerch and Spieth, 2013); the use of formal management methods, such as financial (Jugend et al., 2016) and scoring (Bitman and Sharif, 2008); and the association between the product portfolio and strategic planning (Brook and Pagnanelli, 2014).

In order to provide PPM support, Jugend and Silva (2014) proposed a framework that is based on the three dimensions of Methods, Organization and Strategy. This is the only framework that we find in the literature to support PPM. In this framework, mechanisms such as financial, scoring and ranking, for example, are part of the dimension of Methods. Elements such as profile and leadership style, the need for functional integration and organizational structures for PPM are addressed by the organizational dimension. The relationship between the PPM and the strategic planning processes and their respective revisions is part of the Strategy dimension.

\subsection{Ecodesign}

Ecodesign aims to design products where the minimizing of their environmental impact throughout their life cycle is 
considered (Karlsson and Luttropp, 2006; Jabbour et al., 2018). In an ecodesign-based product, design, quality and customer satisfaction requirements must be integrated with environmental requirements, so that solutions are considering their impact during all stages of the product life cycle, from raw material extraction through to manufacturing, packaging, use, recycling and reuse (Bovea and Perez-Belis, 2012; Luiz et al., 2016).

However, it is known that many companies face trade-offs among the development of environmentally sustainable products including in areas such as their production costs, final prices, functions that the product can perform and its environmental impact (Luchs et al., 2012). When adopting an ecodesign, the objective is to find a balance between requirements and environmental impacts and these functionalities and good performance in NPD (Luttropp and Lagerstedt, 2006; Pigosso et al., 2013). Thus, ecodesign aims essentially to contribute to the development of eco-efficient products, implying the initial considerations of environmental requirements in the first phases of the NPD without negatively impacting the traditional characteristics of the products, such as design, sales price, reliability, time to market, among others (Pigosso et al., 2010).

Ecodesign and concern for green product development can also help organizations achieve benefits: (i) economics, such as optimization of raw material consumption and energy use, reduction of water consumption, improvement of waste management, reduction of production costs (Bocken et al., 2014; Fiksel, 2012); (ii) market, achieving higher customer satisfaction, gaining new customers, acquiring a better reputation and higher sales (Dangelico, 2017); (iii) innovation, related to the application of ecoinnovation and new technologies of product and process (Bocken et al., 2011; Dangelico and Vocalelli, 2017); and, (iv) compliance with legal requirements (Dalhammar, 2106; Vercalsteren, 2001). Therefore, there are a number of publications that recommend the adoption of ecodesign in order to improve the environmental performance of products throughout their life cycle (Brones and Carvalho, 2015; Byggeth and Hochschorner, 2006; Dangelico, 2017; Luiz et al., 2016).

In order to guide companies in applying ecodesign, some studies propose their operationalization through the use of specific practices, methods and tools (e.g., Bocken et al., 2014; Bovea and PérezBelis, 2012; Byggeth and Hochschorner, 2006; Luttropp and Lagerstedt, 2006; Moreira et al., 2015; Rossi et al., 2016), and they note that the more anticipated these adoptions are in the NPD stage, the better environmental gains and impacts that can be achieved in the development of the new product (Collado-Ruiz and Ostad-Ahmad-Ghorabi, 2013; Luiz et al., 2016).

Le Pochat et al. (2007) have classified tools of ecodesign into two groups: one with a qualitative approach, e.g. guidelines, strategies, principles and lists of prohibited or non-recommended materials; and one with a quantitative or semi-quantitative approach, having as examples the MET (materials, energy, and toxicity) matrix, and product life cycle assessment. Other methods are also widely mentioned in the ecodesign literature, such as: environmentalquality function deployment (EQFD), environmental failure mode effects analysis (E-FMEA), and ecodesign checklist (Bovea and Pérez-Belis, 2012; Byggeth and Hochschorner, 2006; Cluzel et al., 2016; Knight and Jenkins, 2009).

\section{Research method}

This research takes a qualitative approach in order to develop a new understanding of the phenomenon of integrating ecodesign with PPM. The development of this research comprised two complementary phases. The first is a theoretical study aimed at identifying and analyzing relevant studies regarding the integration of the themes "PPM" and "ecodesign", which then served as basis for the elaboration of a theoretical framework. The second phase involved workshops for the pilot test evaluation of the framework with teams of product developers from two companies specializing in biodiversity. These companies have different levels of maturity in terms of implementing environmental issues into the NPD. The following discussion details these phases.

\subsection{Phase 1: Review and theoretical analysis}

As noted above, the framework presented in this study was developed from the literature review. To ground the theoretical research, the following terms were considered: "product development process", "product portfolio", "new product development" and "NPD", which were applied in conjunction with: "ecodesign", "eco-design", "green product”, “eco-innovation”, “design for environment" and "DFE". These terms are often used in areas of NPD and PPM (e.g., Cooper et al., 1999; Kester et al., 2014; Jugend et al., 2016), as well as in ecodesign and green product development (e.g., Fiksel, 2012; Luiz et al., 2016; Rossi et al., 2016). The Scopus database was consulted because it is the largest database in the fields of science, technology, medicine, social science, arts and humanities (Fahimnia et al., 2015).

The searches were carried out considering all publications with the key terms relating to the items Title-Abs-Key of Scopus. This resulted in 214 documents, of which 104 were conference papers, 97 articles in journals, five articles in press, four book chapters, and one book. The selection made for inclusion in this study consisted only of articles and articles in press that were published in journals, because such documents pass through stricter criteria of evaluation before publication. The elimination of duplicates and other types of documents (books, book chapters, and conference articles) resulted in 54 publications, which were then read. In addition, we added 21 new articles that dealt directly with the two themes (ecodesign and PPM), that were not initially found by the selective key word searches or which were published at a later date than when the original search was carried out (e.g., Rossi et al., 2016; Silvius et al., 2017).

After reading these publications, we interpreted ecodesign practices, methods, and tools that could be applied to PPM. For example, works such as Gouvinhas et al. (2016), Brones and Carvalho (2015), and Prendeville et al. (2014), which dealt with ecodesign, NPD, and project management, helped us to develop the proposed framework. Relevant studies in terms of citations (e.g. Byggeth and Hochschorner, 2006; Knight and Jenkins, 2009), and which dealt with these themes, were also useful for the development of the framework.

The development of the framework was based on the proposal of Jugend and Silva (2014), because this is one of the few found in the literature to support the product portfolio and it has already influenced other works involved with NPD and PPM (e.g., Carbonell and Rodriguez Escudero, 2016; Echeveste et al., 2017; Nyström and Wellander, 2016). However, unlike the objectives of this research, Jugend and Silva's (2014) proposal deals only with PPM, not with integrating issues of environmental sustainability and the development of environmentally sustainable products.

The content analyzed in the literature review of ecodesign allowed for the relationship of most of the dimensions and practices already proposed by Jugend and Silva (2014), but some adjustments in the specific dimensions of the framework and insertion of content in ecodesign were made. For example, because similar content has not been applied to financial methods in ecodesign practices and methods (which is different from traditional PPM), these methods were not considered in the framework proposed in this article. 
Some practices that were identified as relevant to ecodesign, which were not proposed in the Jugend and Silva (2014) article, were also included in this study. This included "sustainable development guides" and "top management support". On the other hand, "organizational structure" and "strategic planning" were not changed, since the ecodesign literature is also based on integration that considers these activities, as already proposed by the mentioned authors.

\subsection{Phase 2: Pilot test assessment of the framework by biodiversity companies}

In order to evaluate the theoretical framework proposed, we consulted practitioners who work in firms that develop products derived from Brazilian biodiversity. To facilitate this, a questionnaire was initially developed to identify and characterize the firms according to their performance in the industry, as well as to identify their respective degree of maturity in issues related to environmental practices. The questionnaire was constructed with predominantly open questions and had the main intention of clarifying how environmental management and ecodesign are adopted and integrated into the company's product portfolio.

The questionnaire was based mainly on the research of Brones et al. (2014), which involved a case study and focused on identifying how environmental dimensions and ecodesign can be integrated into the management practices of NPD projects. However, we have adapted the issues to focus more on PPM. To evaluate this questionnaire, we first applied it to a large company that develops environmental projects in civil construction and which is certified by ISO 9001: 2015, ISO 14001:2004, and OHSAS 18001:2007. An overview of the questionnaire can be found in the Appendix.

For the examination of the theoretical framework, we looked for companies to participate in evaluation workshops based on the following criteria: that they have new product development activities, they frequently renew their portfolio, and they belong to the biodiversity sector. An internet search was undertaken with the objective of finding companies that fulfilled this profile. After this, telephone and e-mail contact were made with five companies that met these requirements, with three of them answering the contact and accepting the invitation to receive the questionnaire. Thus, the questionnaire was sent to these three companies, two of which showed an interest in participating in the research, responding to the material by e-mail and organizing an agenda of meetings in order to discuss answers to the questionnaire and receive the researchers.

We also aimed to evaluate the framework in companies with different degrees of maturity in environmental sustainability. For this, we used a classification suggested by Gouvinhas et al. (2016), with six stages of maturity (i.e., level 1 being completely immature and level 6 being fully mature). Initial meetings were held with companies $\mathrm{A}$ and $\mathrm{B}$ which allowed a better understanding of their practices of environmental sustainability, ecodesign, and PPM. In the next stage, we conducted workshops with these same firms in order to evaluate the framework.

\section{- Characterization of companies}

Due to issues of confidentiality, the companies will be referred to as company A and B in this article. Company A was founded in 1994 and has its administrative headquarters in the city of Sao Paulo, as well as operating a factory in the countryside of the state of Sao Paulo (Brazil). It currently has 434 employees and was a pioneer in raising poultry with no antibiotic and growth promoters in Brazil, which is free of both antibiotics and artificial growth promoters. In its mission, the company aims to integrate ecological and social values in the development and production of natural foods that are free of agrochemicals. In 2017, the company was acknowledged by the Brazilian Council for Organic and Sustainable Production as being the most recognized brand in organic products in Brazil.

This company's product portfolio consists of organic foods, antibiotic-free chicken meat and eggs, organic honey, organic and sustainable coffee, organic seeds. With the objective of developing eco-efficient packaging, the company has carried out tests with packaging made from manioc starch, which is totally biodegradable. Based on their responses to the first questionnaire, we realized that company A demonstrate concern with the entire supply chain cycle. These concerns guide the company, from choosing their portfolio and defining the concept of products from production to discontinuity, and involves applying knowledge from areas such as biology, food engineering and chemistry.

Company B operates in the timber industry and is in its second generation of family management. Founded in 1992, its production plants and its main office are located in the south-west of the state of Sao Paulo (Brazil) and it currently has 80 employees. The firm has a portfolio of products derived from reforestation eucalyptus wood, among which are toys for playgrounds (balances and seesaws, including ones that accommodate disabled children), equipment for gymnastics, showers and sinks with wood bases, and other such products. In addition, the company is currently responsible for an inclusive social project in Sao Paulo state called "old people's square", in which it has developed and manufactured several ergonomic gymnastic devices for physical movement across more than 400 towns and cities in this region of Brazil.

Based on the responses received in the questionnaires and from information gathered at the meetings that were held, companies A and $B$ were classified according to the proposal of Gouvinhas et al. (2016), with company A qualifying as a level 5 company (more mature) and company B as level 2 (less mature). Company A demonstrated the characteristics present at level 5 of maturity (Gouvinhas et al., 2016), because the company has demonstrated activities including considering environmental issues in their business decisions, requiring suppliers to meet environmental standards, and educating their clients to consider environmental and social aspects during their consumption decisions. In addition, they have formalized environmental processes (for products and processes) and already apply ecodesign methods and tools.

Due to the characteristics identified in company B, it qualifies as an immature company (level 2 maturity) (Gouvinhas et al., 2016) because, while it is a firm that has started to experiment with ecodesign. For Gouvinhas et al. (2016), at level two, companies are still more concerned with the problems of profitability, cost reduction, and production efficiency, rather than environmental aspects; however, they do already understand the importance for new market opportunities that focus on aspects environmental and social issues and try to implement projects in this field.

\section{- Workshops for the evaluation of the framework}

For the second phase of this research, workshops were held in both companies to evaluate and pilot test the framework developed. An initial meeting was scheduled to discuss the practices of PPM and ecodesign in the firms, and later a second meeting was held in the form of workshops in which the proposed theoretical framework was presented for evaluation by managers. The industrial director and the research assistant participated in the meetings and workshops at company A. In company B, the workshop was attended by the director, the human resources manager, and the forestry engineer.

In this phase, all the dimensions and theoretical groupings within the framework were presented and discussed in detail. The 
objective of this activity was to obtain a better understanding of the applicability of the proposed activities to the everyday reality of these firms. During the workshops, we also asked for suggestions of other activities common to the practices of the companies that were not mapped in the literature, and that consequently were not present in the proposed framework.

\section{Results}

Initially this section presents the theoretical framework that was developed and proposed. Then, the results of the evaluations of this framework by the two companies selected are presented.

\subsection{Framework for the integration of ecodesign on product portfolio management}

Initially, it is important to highlight that although it is known that ecodesign has many management practices (Rossi et al., 2016), the development of this framework has considered only to those in which it was interpreted to have a possibility of practical application in the PPM, that is, in the planning stage of the NPD process. Fig. 1 presents an overview of the proposed framework. Each one of the proposed dimensions is explained in the following paragraphs.

\section{- Dimensions of Guides, Methods and Tools}

Consideration of a dimension for the adoption of guidelines and formal application of methods and tools is relevant to our subject of environmentally sustainable products, due to the need for companies to evaluate product projects and their environmental impact from formal and previously defined evaluations (Bovea and PérezBelis, 2012). Diagrams, tools, checklists and guidelines are means for the adoption of environmental considerations into NPD (Rossi et al., 2016). However, as observed by Alblas et al. (2014) and
Driessen et al. (2013), due to a lack of specific knowledge in ecodesign tools, some companies fail to consider the adoption of their practices in product project decisions, which may undermine environmental performance.

Because of this potential pitfall, the literature tends to defend the application of tools and methods that have a simple application in traditional portfolio management (Jugend and Silva, 2014) as well as for the adoption of ecodesign (Byggeth and Hochschorner, 2006; Cluzel et al., 2016). The use of easy-to-apply tools and methods in the development of green products increases the possibility of companies overcoming limitations and barriers to their application, as well as optimizing the time and resources available for selecting and applying them (Ammenberg and Sundin, 2005). Table 1 presents the summary of the Guides, Methods and Tools dimension.

Among the suggested methods and tools, the ecodesign checklist method, scoring and ranking can be useful to PPM, since they are related to the life cycle of the products, evaluating criteria such as simplicity of the project execution; selection and decrease of the use of raw materials; the reduction of energy use; reduction of losses during use and at the end of use; reduction of the product's time of disassembly; and reuse and recycling and of the product, among others (Knight and Jenkins, 2009). The use of checklists and scoring mechanisms also allows managers to obtain a list with the classification of projects already ranked, which supports better environmental decision making in the projects yet to be effectively developed (Vezzoli and Sciama, 2006).

Diagrams and matrices are visual mechanisms that can promote the adoption of the life cycle approach and provide an illustrative way to evaluate the interactions between product design criteria, which may favor product portfolio decision making. Among these mechanisms are the matrices such as the MECO Matrix (Byggeth and Hochschorner, 2006) and the Matrix of Material, Energy and Toxicity (Knight and Jenkins, 2009) and the ecodesign strategy

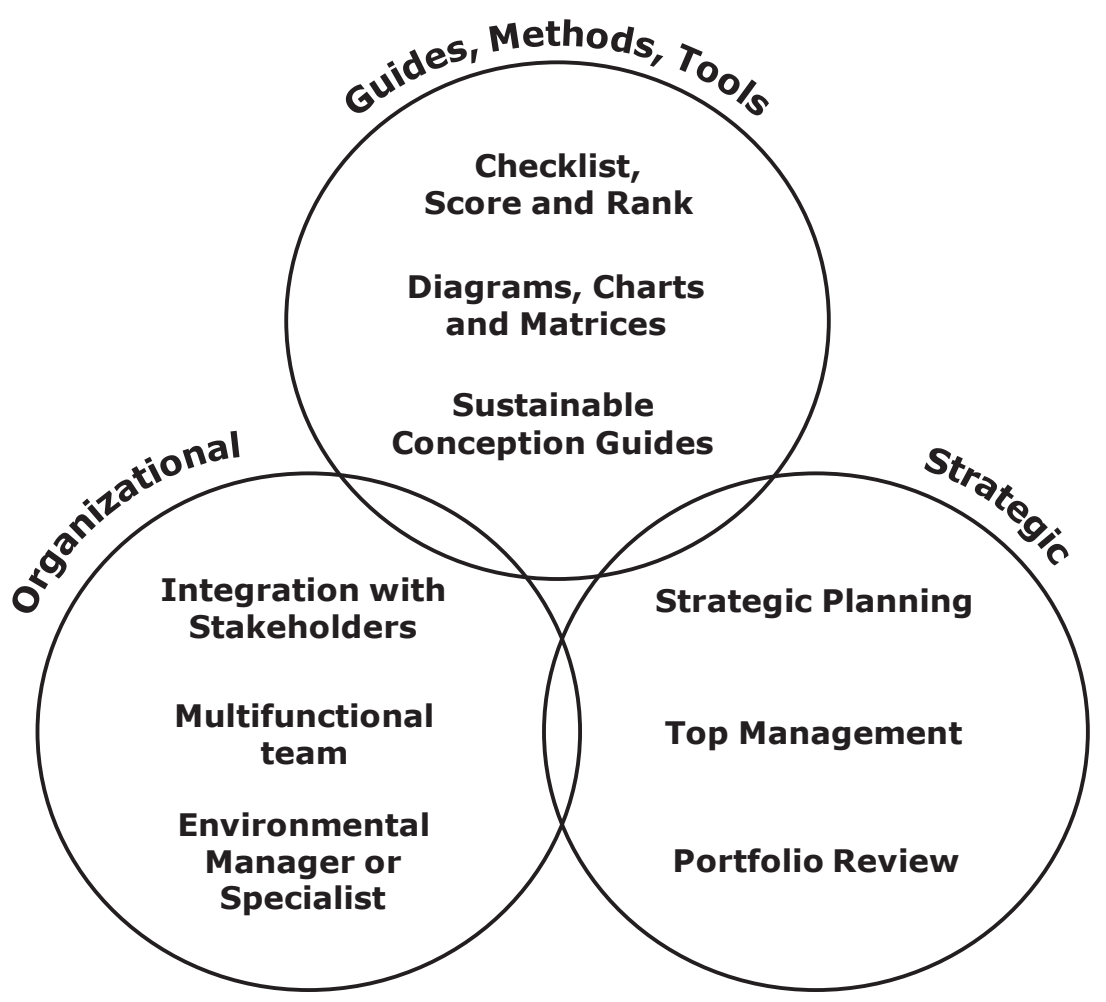

Fig. 1. An overview of the framework for integration between product portfolio management and ecodesign. 
Table 1

Dimension: Guides, methods and tools.

\begin{tabular}{|c|c|c|c|c|}
\hline Dimension & $\begin{array}{l}\text { Guides, } \\
\text { Methods, } \\
\text { Tools }\end{array}$ & Applications & Examples & References \\
\hline \multirow[t]{2}{*}{ Group } & $\begin{array}{l}\text { Checklists, } \\
\text { Scoring and } \\
\text { Ranking }\end{array}$ & $\begin{array}{l}\text { They have the potential to verify if environmental parameters are } \\
\text { considered in PPM. They can be useful in the selection and } \\
\text { prioritization of product projects by employing predefined } \\
\text { evaluation criteria. }\end{array}$ & $\begin{array}{l}\text { Ecodesign checklist } \\
\text { method. }\end{array}$ & $\begin{array}{l}\text { Rossi et al. (2016); Knight and Jenkins } \\
\text { (2009); Vezzoli and Sciama (2006); } \\
\text { Byggethand and Hochschorner (2006). }\end{array}$ \\
\hline & $\begin{array}{l}\text { Diagrams } \\
\text { and } \\
\text { Matrices } \\
\text { Sustainable } \\
\text { Guides }\end{array}$ & $\begin{array}{l}\text { These allow estimation of the potential for improvement in the } \\
\text { environmental performance of the projects of evaluated products. } \\
\text { They can provide forecasts related to the product life cycle. } \\
\text { Management models can assist decision making regarding } \\
\text { environmentally sustainable product projects. }\end{array}$ & $\begin{array}{l}\text { Ecodesign strategy wheel, } \\
\text { materials energy \& } \\
\text { toxicity (MET) matrix. } \\
\text { ISO } 14062: 2002, \text { BS8887- } \\
1: 2006 .\end{array}$ & $\begin{array}{l}\text { Rossi et al. (2016); Knight and Jenkins } \\
\text { (2009); Le Pochat et al. (2007); Byggeth and } \\
\text { Hochschorner (2006). } \\
\text { Luttropp and Lagerstedt (2006); Vezzoli } \\
\text { and Sciama (2006). }\end{array}$ \\
\hline
\end{tabular}

wheel (Cluzel et al., 2016). The filling of these matrices can be done by asking a question and choosing a value to sort the attribute analyzed, and the results can be used to compare new product projects with an existing reference product or to compare various environmental alternatives for product projects (Byggeth and Hochschorner, 2006).

Sustainable product development guides can be used to support companies with systems and procedures that facilitate decision making that consider the integration of environmental aspects with product development projects (Bocken et al., 2014). An example is ISO/TR 14062:2004, which involves environmental management and characterizes concepts and practices relating to the integration of environmental aspects into product project, design and development. Another example is BS 8887-1: 2006, which establishes general concepts, processes and requirements, a checklist with guidance for the delivery of sustainable materials and components from design to fabrication, assembly, disassembly and final processing of life (British Standards Institution, 2006).

\section{- Dimension of Organization}

Given that organizational aspects should not be neglected for product portfolio decision making, this dimension considers elements such as: integration with stakeholders; multidisciplinary team; and environmental manager or specialist when planning the adoption of ecodesign in PPM. Table 2 presents an overview of this dimension.

Considering the organizational design, integration with stakeholders is a relevant element for the improvement of the decisionmaking process in the portfolio of environmentally sustainable products since it also facilitates the identification of external factors of environmental regulation and consumer demand for environmentally sustainable product. In addition to facilitate the identification of external factors of environmental regulation and consumer demand for environmentally sustainable products, it may also favor the sharing of knowledge and information of perspectives and technical environmental aspects of different stakeholders in the product project decision (Hoejmose et al., 2012; Marcelino-Sádaba et al., 2015; Vezzoli et al., 2012). Juntunen et al. (2016) emphasize the importance of integrating with stakeholders in the development of environmentally sustainable products, because this involvement allows greater integration of knowledge from internal and external sources to the company, aiming at what has the potential to generate more information on the sustainability aspects of products.

Multidisciplinary teams that have participation of members from several areas and specialties of the firm can be considered relevant for the development of environmentally sustainable products and can positively impact portfolio management (Hyung Jin Park et al., 2009). In these teams, the participation of environmental specialists tends to favor the adoption of ecodesign methods and tools to choose products of environmentally sustainable products in the composition of the portfolio (Bocken et al., 2014; Jabbour et al., 2015). Also, the integration of ecodesign to the PPM tends to succeed more and to be carried out by employees who are committed to respecting the regenerative capacity of the nature and thus to develop mechanisms to review and to redesign traditional solutions in the development of products (Petala et al., 2010; Prendeville et al., 2014). Therefore, it is important that employees with this profile participate or lead the new product development teams.

In addition to the adoption of multifunctional teams, the literature has also indicated the relevance of the presence of leaders or managers who have the technical skills and management involved in the NPD process (Jugend and Silva, 2014; Prendeville et al., 2014). In this sense, researchers such as Borchardt et al. (2010) and

Table 2

Dimension: Organization.

\begin{tabular}{|c|c|c|c|c|}
\hline Dimension & Organization & Applications & Examples & References \\
\hline \multirow[t]{3}{*}{ Group } & $\begin{array}{l}\text { Integration with } \\
\text { Stakeholders }\end{array}$ & $\begin{array}{l}\text { Receiving the opinions of different stakeholders } \\
\text { concerning product portfolio decisions. }\end{array}$ & $\begin{array}{l}\text { Workshops to sensitize and receive } \\
\text { ideas, opinions, suggestions regarding } \\
\text { environmental aspects of the different } \\
\text { stakeholders of product projects. }\end{array}$ & $\begin{array}{l}\text { Juntunen et al. (2016); Salem et al. } \\
\text { (2016); Marcelino-Sádaba et al. } \\
\text { (2015); Pigosso et al. (2013); Hoejmose } \\
\text { et al. (2012); Vezzoli et al. (2012). }\end{array}$ \\
\hline & $\begin{array}{l}\text { Multifunctional } \\
\text { Team }\end{array}$ & $\begin{array}{l}\text { A team with representatives from the different } \\
\text { areas/departments, including environmental } \\
\text { ones, incorporating information and suggestions } \\
\text { received from the product planning stage. }\end{array}$ & $\begin{array}{l}\text { Multifunctional teams involved in the } \\
\text { new product development with a } \\
\text { representative of the environmental } \\
\text { area/function. }\end{array}$ & $\begin{array}{l}\text { Bocken et al. (2014); Jabbour et al. } \\
\text { (2015). }\end{array}$ \\
\hline & $\begin{array}{l}\text { Environmental } \\
\text { Manager or } \\
\text { Specialist in the } \\
\text { Development }\end{array}$ & $\begin{array}{l}\text { Provides management information, translating } \\
\text { technical environmental possibilities to other } \\
\text { functions involved in the new product } \\
\text { development. }\end{array}$ & $\begin{array}{l}\text { Leader with technical knowledge in the } \\
\text { environmental area and also } \\
\text { managerial. }\end{array}$ & $\begin{array}{l}\text { Prendeville et al. (2014); Petala et al. } \\
\text { (2010); Borchardt et al. (2010); } \\
\text { Johansson (2002). }\end{array}$ \\
\hline
\end{tabular}

Team 
Johansson (2002) suggest that the presence of ecodesign experts contributes to the application of ecodesign in NPD decision making.

\section{- Dimension of Strategy}

Portfolio decisions tend to reflect strategic planning deliberations (Kopmann et al., 2015) and its periodic review activities (Jugend and Silva, 2014; Patterson, 2005). Similarly, decisions about the development of environmentally sustainable products and the adoption of ecodesign can also be aligned and their adoption intensified through the strategic activities of firms. This dimension is illustrated in Table 3.

In the face of strategic planning activities, some studies suggest the importance of linking the business strategy with the decision making in a portfolio of environmentally sustainable products (e.g., Byggeth and Hochschorner, 2006; Gouvinhas et al., 2016). Byggeth and Hochschorner (2006) identified that the application of ecodesign tools in strategic planning tends to positively influence firm performance. Gouvinhas et al. (2016) indicate the alignment between strategic planning and the effective adoption of ecodesign as an indication of maturity in environmental sustainability.

Another relevant factor for the consideration of environmental aspects in the development of environmentally sustainable products is the support of the top management (Petala et al., 2010), which can be a critical success factor for the adoption of ecodesign in moments of product portfolio decision making, whether in strategic planning (medium and long term) or portfolio review moments (short term).

Considering the market dynamics and the complexity of product development decision-making in strategic planning, it is important to carry out portfolio review activities in short periods of time to verify the alignment of projects with strategic planning (Patterson, 2005). For this operationalization, Goffin (2012) recommends integrating environmental sustainability with the NPD process through the stage-gates model during product development decisions. In addition to strategic approvals and decisions, portfolio reviews in project development forums can also be used to verify that projects meet environmental requirements, thus ecodesign methods and tools can also be incorporated into the stage-gates model.

\subsection{Evaluation of the framework by companies}

As detailed in the section of research method, with the objective of evaluating the theoretical framework developed in firms, presentations and interviews were conducted in a workshop format in Brazilian companies that develop products based on biodiversity and with different levels of maturity in the adoption of ecodesign. Table 4 presents the results of the Guides, Methods and Tools dimension.
Table 4

Results of the framework analysis (Guides, Methods and Tools dimension).

\begin{tabular}{|c|c|c|}
\hline Dimension & \multicolumn{2}{|c|}{ Guides, Methods and Tools } \\
\hline Proof quotes & Company A & $\begin{array}{l}\text { - In relation to sustainable development guides, } \\
\text { the philosophy of natural agriculture is our } \\
\text { guide, providing what we consider about } \\
\text { sustainability, and it is precisely in this } \\
\text { philosophy that we base ourselves, being our } \\
\text { guide in relation to what will or will not be done. } \\
\text { - An environmental checklist template was created } \\
\text { by the product development team that is } \\
\text { completed and discussed during product } \\
\text { portfolio meetings. Before the product project } \\
\text { goes into development, it goes through the } \\
\text { checklist and through method evaluations, scores } \\
\text { and rankings, and after that the management of } \\
\text { this process is done by the product development } \\
\text { sector, with the PMO (project management } \\
\text { office) practices, which establishes } \\
\text { methodologies and supports with documents and } \\
\text { tools. }\end{array}$ \\
\hline & Company B & $\begin{array}{l}\text { - The application of tools before starting the } \\
\text { production process would be positive; it would } \\
\text { be great, both guides and checklists. Today we } \\
\text { can identify failures in the development of some } \\
\text { projects that, if they had been better evaluated, } \\
\text { could have been avoided. } \\
\text { - The tools checklist, matrix and diagrams are } \\
\text { applicable; I can undoubtedly see myself } \\
\text { applying these tools. Just so you can see, I can } \\
\text { align with the work of production planning and } \\
\text { control with these tools, the applicability is total. }\end{array}$ \\
\hline Relations with & literature & $\begin{array}{l}\text { Agreement that the use of traditional ecodesign } \\
\text { tools may be useful to PPM. }\end{array}$ \\
\hline $\begin{array}{c}\text { Differentiation } \\
\text { literature }\end{array}$ & from the & $\begin{array}{l}\text { It uses specific guides already developed for } \\
\text { specific industrial sectors - in this case for the } \\
\text { biodiversity sector. (company A) } \\
\text { Application of ecodesign methods and tools in } \\
\text { PPM can be enhanced through specialized } \\
\text { organizational structure, in this case the Project } \\
\text { Management Office -PMO. (company A) } \\
\text { It does not adopt traditional ecodesign methods } \\
\text { and tools that could be used in PPM, such as: } \\
\text { EQFD, E-FMEA or MET matrix. } \\
\text { They do not adopt guides recognized as ISO } \\
\text { 14062: 2002. (both companies) However, they } \\
\text { adopt procedures already established by the } \\
\text { sector, such as the philosophy of natural } \\
\text { agriculture. (company A). }\end{array}$ \\
\hline
\end{tabular}

The application of environmental checklist methods, scoring and ranking for the analysis of product projects, as well as the adoption of natural agriculture guides are practical examples adopted by company A in PPM and are aligned with the proposed framework. Company B, not adopting these formal methods and

Table 3

Dimension: Strategy.

\begin{tabular}{|c|c|c|c|c|}
\hline Dimension & Strategy & Applications & Examples & References \\
\hline \multirow[t]{3}{*}{ Group } & $\begin{array}{l}\text { Strategic } \\
\text { Planning }\end{array}$ & $\begin{array}{l}\text { Incorporate environmental and product life } \\
\text { cycle aspects in product decisions related to } \\
\text { strategic planning. }\end{array}$ & $\begin{array}{l}\text { The firm's strategic plan contains objectives and } \\
\text { information related to the application of ecodesign } \\
\text { methods and tools in the product portfolio. }\end{array}$ & $\begin{array}{l}\text { Gouvinhas et al. (2016); Brones } \\
\text { and Carvalho (2015); Byggeth and } \\
\text { Hochschorner (2006); Simon et al. } \\
\text { (2000). }\end{array}$ \\
\hline & $\begin{array}{l}\text { Support } \\
\text { from Top } \\
\text { Management }\end{array}$ & $\begin{array}{l}\text { Support and encourage only the } \\
\text { development of products that are aligned } \\
\text { with environmentally sustainable design and } \\
\text { development. }\end{array}$ & $\begin{array}{l}\text { Top management defines policies that prioritize the } \\
\text { development of environmentally sustainable products. }\end{array}$ & $\begin{array}{l}\text { Borchardt et al. (2010); Petala et al. } \\
\text { (2010). }\end{array}$ \\
\hline & $\begin{array}{l}\text { Portfolio } \\
\text { Review }\end{array}$ & $\begin{array}{l}\text { Evaluate and decide, at previously defined } \\
\text { moments, the prioritization or cancelation of } \\
\text { projects according to environmental impact } \\
\text { criteria. }\end{array}$ & $\begin{array}{l}\text { Use of Go/No Go environmental criteria at the time of } \\
\text { phase evaluation during pre-development and } \\
\text { decision making, concerning products to be developed, } \\
\text { maintained, or discontinued. }\end{array}$ & $\begin{array}{l}\text { Petala et al. (2010); Brones and } \\
\text { Carvalho (2015). }\end{array}$ \\
\hline
\end{tabular}


tools, suggested that their use could effectively improve the management of choice of environmentally sustainable products and was interested in adopting the proposed methods and tools in the framework.

It was added by company $A$ that the activities related to product portfolio management are managed by the new product development department, using the Project Management Office (PMO) organizational structure, which establishes methods and supports the management of new product projects and the environmental methods and tools associated with this process.

Although the companies do not have guides recognized, they adopt other systems that support decision making in environmentally sustainable products such as the philosophy of natural agriculture (company A); and company $\mathrm{B}$ is in the process of being certified by the Brazilian Association of Wood Preservers for the self-evaluation guide, which aims to guarantee the quality and legality of the consumer of treated wood products. Table 5 presents the results of the evaluation concerning the Organization dimension.

Regarding organizational aspects, company A highlighted the use of information from social medias as a mechanism that intensifies integration with its stakeholders. Because it is a company that deals with biodiversity, the integration of users into its product projects through the medias can be higher than with companies from other sectors due to the greater concern of this type of consumer with the preservation of biodiversity. This fact may favor the

Table 5

Results of the framework analysis (Organization dimension).

\begin{tabular}{|c|c|c|}
\hline Dimension & Organization & \\
\hline \multirow[t]{2}{*}{ Proof quotes } & Company A & $\begin{array}{l}\text { In the organizational point of view there is an } \\
\text { environmental work with a focused work team; } \\
\text { there are indicators of environmental and } \\
\text { technical issues in partnership with EMBRAPA } \\
\text { (Brazilian agricultural research corporation). } \\
\text { There is in our case, not necessarily the } \\
\text { manager, but a person who has the expertise to } \\
\text { monitor the projects. } \\
\text { There is also a multidisciplinary structure, as it } \\
\text { has departments with professionals in its areas, } \\
\text { including those with several areas of knowledge } \\
\text { participating in the projects. } \\
\text { Integration with stakeholders happens } \\
\text { internally and externally to satisfy the } \\
\text { consumer. We collect data and information on } \\
\text { social networks and with our suppliers. }\end{array}$ \\
\hline & Company B & $\begin{array}{l}\text { Without the support of top management, a } \\
\text { simple environmental initiative can find } \\
\text { implementation barriers, since the function can } \\
\text { be focused on the result of the operation and } \\
\text { deprioritize the environmental aspect. } \\
\text { Perhaps in some situations in smaller companies } \\
\text { the presence of a consultant with specific } \\
\text { knowledge may be relevant. This would be } \\
\text { useful if it was not possible to have the full } \\
\text { dedication of this employee due to the size and } \\
\text { profile of the company. }\end{array}$ \\
\hline $\begin{array}{l}\text { Relations with } \\
\text { literature }\end{array}$ & Both & $\begin{array}{l}\text { Adoption of multifunctional teams; presence } \\
\text { of environmental specialist in product } \\
\text { development teams, integration with } \\
\text { stakeholders; top management support for } \\
\text { the development of environmentally } \\
\text { sustainable products. }\end{array}$ \\
\hline $\begin{array}{l}\text { Differentiation } \\
\text { from the } \\
\text { literature }\end{array}$ & Company A & $\begin{array}{l}\text { Use of social networks to collect information } \\
\text { on the development of environmentally } \\
\text { sustainable products; support of research- } \\
\text { oriented institutions (in this case, EMBRAPA). } \\
\text { External ecodesign specialist in product } \\
\text { development teams. }\end{array}$ \\
\hline
\end{tabular}

company's ability to understand stakeholder needs in product development decisions, especially customers and representatives of society who are involved in biodiversity issues.

The support of research institutions that are focused on agricultural research (in this case, The Brazilian Agricultural Research Corporation - Embrapa) was also reported as a relevant practice by company A for reinforcing the effective adoption of environmental policies and guidelines for the decision-making processes relating to products, thereby maintaining a sustainable point of view, since it inserts an external environmental specialist into the process that acts in the research institute in PPM. Although the two companies recognized the need for the participation of a multidisciplinary team in NPD projects with the presence of an environmental specialist, it was highlighted by the director of company B that smaller companies may not have a qualified professional completely dedicated to these works, noting that it is important to consider also the hiring of an external consultant with specific knowledge to participate in shorter periods of time in these teams. Table 6 presents the results of the Strategy dimension.

The two companies emphasized that integrating environmental sustainability and applying ecodesign practices in PPM is only possible when top management offers support from the strategic planning stages. The fact that top management members of the company A participate in portfolio review meetings and support environmental sustainability right from the stage of strategic planning is an element of organizational culture that is oriented toward sustainability and can be considered a practice that strengthens the achievement of strategic environmental objectives. This is due to the support for product development that is aligned with environmentally sustainable design and development. In company B it was pointed out that if the integration of ecodesign in the projects does not make sense to the top management, there will be no prioritization in the selection of the projects of new products with the environmental aspects. It was reported that while the application of the environmental checklist, it is necessary to know if the requirements listed in this method are aligned with the strategic objectives of the firm.

Company A has adopted stage-gates model and illustrated its use in their planning product phase when in the technical

Table 6

Results of the framework analysis (Strategy Dimension).

\begin{tabular}{|c|c|c|}
\hline Dimension & Strategy & \\
\hline \multirow[t]{2}{*}{ Proof quotes } & Company A & $\begin{array}{l}\text { We hold portfolio meetings, both updates and } \\
\text { progress of the projects, as well as validations } \\
\text { and discussion of possible barriers identified. For } \\
\text { example, we were in the final stages of planning } \\
\text { a product when it was realized that the issue of } \\
\text { not using hormones would be a technological } \\
\text { difficulty, so the process was stopped because it } \\
\text { ran away from our principles. }\end{array}$ \\
\hline & Company B & $\begin{array}{l}\text { The company's strategy is to operate in the } \\
\text { market with environmentally sustainable } \\
\text { products. To this end, top management directs } \\
\text { product development activities from the } \\
\text { selection of raw material from reforestation. } \\
\text { Without the support of top management, a } \\
\text { simple environmental initiative can find } \\
\text { implementation barriers, because the operator } \\
\text { may be focused on the output of the production } \\
\text { and not prioritize the environmental aspect. }\end{array}$ \\
\hline $\begin{array}{l}\text { Relations with } \\
\text { literature }\end{array}$ & $\begin{array}{l}\text { Company A } \\
\text { Both }\end{array}$ & $\begin{array}{l}\text { Use of stage-gate for product portfolio review. } \\
\text { Top management support in the strategy of } \\
\text { acting in the market for environmentally } \\
\text { sustainable products. }\end{array}$ \\
\hline $\begin{array}{l}\text { Differentiation } \\
\text { from the } \\
\text { literature }\end{array}$ & Both & Nothing found. \\
\hline
\end{tabular}


evaluation of the gate, it was verified that it would be necessary to use hormones in the new product. As the use of hormones in the product portfolio is misaligned with the strategic positioning of the company, the project was canceled. Respondents from company B emphasized that by positioning themselves in the market for environmentally sustainable products, they are concerned with the environmental impacts throughout the life cycle of their product, from the selection of raw material (reforestation wood only) to the reuse techniques in the use of new products derived from wood, for example, applying them on dormant landscaping and using them as organic matter.

Finally, comments made by company A's product team during the workshop suggest that the framework developed in this paper and presented to the firms (Fig. 1) has the advantage of offering an organized visual approach to the adoption of ecodesign in the PPM context.

\section{Discussion}

Regarding the existing literature, the framework proposed here adds a set of dimensions in terms of management and groups of activities that contribute to the integration of environmental aspects of portfolio management and green product development. This study stands out from existing literature, not only for examining the possibilities of integrating ecodesign tools and methods during the early stages of NPD, but also by merging that with organizational and strategic approaches. Studies that suggest the adoption of environmental issues in the early stages of NPD have focused mainly on methods and tools (e.g., Chang et al., 2013; Koga and Aoyama, 2008; Ölundh and Ritzén, 2004). Even this framework been constructed based on ecodesign, there are synergies between this study and the proposal of Brook and Pagnanelli (2014), which aimed to integrate sustainability in its three dimensions (economic, social, and environmental) into breakthrough projects, platform projects, and derivative projects.

When analyzing the theoretical framework in relation to the reality of the companies, it was observed that there was a greater adherence to the methods and tools found in the literature in company A. This firm is more mature in terms of environmental management, and effectively adopts practices such as gates for portfolio review and formal ecodesign tools, such as an environmental checklist and scoring models (Bovea and Pérez-Belis, 2012; Brones and Carvalho, 2015; Byggeth and Hochschorner, 2006). Practices such as offering support from top management (Dangelico, 2017; Petala et al., 2010) and the formation of multifunctional teams (Bocken et al., 2014; Jabbour et al., 2015) for decision making in relation to environmentally sustainable products are adopted by both companies, which demonstrates that the organizational aspects proposed in the framework are reflected in practice.

Although the PMOs are consolidated structures in the areas of project management and NPD (Bredillet et al., 2017; Unger et al., 2012), little is known about their application in projects that involve environmental sustainability. The possibility of incorporating the PMO as a structure that can support the adoption of ecodesign in PPM was a relevant contribution used by company A for the proposed framework. This practice can integrate the ideas of environmental sustainability as a school of thought in project management (Silvius et al., 2017).

Policies that support R\&D and open innovation through partnership with agencies, institutions, and consultancies were also noted by both firms as being a common practice and were not initially mapped in the specific literature that addresses ecodesign and PPM. In company A, for example, there is a team working in partnership with the Brazilian Agricultural Research Corporation (EMBRAPA) towards the development of indicators of environmental and technical issues that assist with decision making in environmentally sustainable products. In company B, it was highlighted that they use expert consultants or the support of agencies such as the Brazilian Micro and Small Business Support Service (SEBRAE). This confirms the proposal made by researchers such as Borchardt et al. (2010) and Johansson (2002), that the presence of an environmental specialist, even if not in full-time, was pointed out as a possible contribution to the decision making and product portfolio.

With regard to open innovation and user involvement in the development of environmentally sustainable products, it was identified in the study of company A that the exchange of information through social networks is a relevant way of building relationship with the consumer and society, which was not included in the initially proposed framework. This activity seems to contribute positively to the process of monitoring the demands of the market, serving as one of the sources for the process of generating ideas for new product projects in the company. As this company is involved in biodiversity-based product development, there is a greater participation of consumers and other actors in society, who are traditionally more active and concerned with preserving biodiversity when compared to other economic sectors.

The observed synergy between environmental and social aspects is an important observation of the workshops. Both companies emphasized environmental and social practices as being inseparable, and demonstrated a strong relationship between these. This is supported by the proposal of Gouvinhas et al. (2016), which characterizes more mature companies as having the responsibility of trying to educate clients towards more conscious social behavior. For example, company A aims to integrate ecological and social values into the development and production of natural foods, and company B is currently responsible for an inclusive social project aimed at the elderly, as well as for developing products aimed at disabled children.

\section{Conclusions}

The framework proposed here aimed to meet an identified gap in the literature; namely, the need to consider environmental aspects from the earliest stages of NPD. By proposing a framework that was developed theoretically, and then evaluated by companies that develop products based on Brazilian biodiversity, the results presented here help to advance areas such as environmental sustainability, NPD, and project management. This framework systematizes a set of managerial practices that can facilitate the integration of ecodesign in PPM. Few investigations analyze these areas in an integrated manner, and the integration of ecodesign and project management has been called for in recent literature on environmental sustainability and project management.

With regards to managerial implications, we understand that the framework can guide managers from diverse companies (not just those of biodiversity companies) to adopt or intensify ecodesign and environmental concerns when making choices about new products, as well as determining resource allocation activities among these projects. For example, the need to train PMO managers in ecodesign activities was found in this study, which could facilitate the integration of ecodesign into PPM.

Despite the results obtained, this research also presents some limitations. Firstly, certain ecodesign tools and methods found in the literature present application restrictions during PPM but can be applied in other stages of the NPD process, for example, in the conceptual and detailed design stages. Second, the evaluation of the framework focused its research on only one food industry and one on the timber industry, which has a direct relationship with biodiversity. It is possible that other industries, such as those belonging to the electronic and automotive sectors could evaluate 
the conceptual framework differently, which would generate new and alternative results compared to those outlined by this research. As such, it is recognized that the empirical results of this study should be viewed with due methodological caution, since its results cannot be generalized.

Based on the results and limitations of this research, with the objective of identifying new practices for the integration of environmental sustainability in PPM, we understand that future research, also using a qualitative approach, could undertake complementary studies in companies that work in different sectors and environments, including high-tech companies, for example. Another important area for future studies would be to verify the possibility of financial environmental evaluations, which were not identified in the literature in ecodesign, or even highlighted in the framework's evaluation workshops. This theoretical framework can be improved, not being a definitive effort. It can be continually improved, either by means of new theoretical research or by empirical evaluations, which also suggests an important role for future studies.

\section{Acknowledgements}

This research was funded by FAPESP - The Sao Paulo State Research Foundation, Brazil (Grant \# 15/00110-6). The authors would like to thank the anonymous reviewers for their valuable comments and suggestions to improve the quality of the paper.

\section{Appendix 1. Overview of Questionnaire}

\section{Part A}

Company and Respondent Identification (Characteristics)

Part B

1. In the new product development process, how does the company select the projects to be developed?

2 . Which stages comprise the process of new product development in the company?

3. Does the company have environmental or ecodesign concerns in the new product development process? How are these identified?

4. Does the company consider environmental criteria when making decisions about which new product projects it selects? How does this process work?

5. Does the company consider environmental criteria in decisions related to technologies chosen or developed for new products? How are these identified?

6. Do environmental issues interfere with the quality of the product project? How does this process work?

7. Do environmental issues interfere with the cost and price of the products? How does this process work?

8. Do environmental decisions interfere with the functional performance of the products?

9. Does the company develop products focusing on reducing resource consumption and waste generation during consumer use of the products? How does this work?

10. Does the company adopt specific ecodesign methods to support decision making on which products to develop? (For example: EQFD, MET matrix; E-FMEA, ecodesign checklist, or other.) Please elaborate.

11. Does the company use guides or specific environmental legislation to guide the development of new products? Please elaborate.

12. What are the main barriers or needs in the incorporation of environmental aspects in new product development process? Please elaborate.
13. In your opinion, how can environmental aspects influence decision making on which new products projects to develop?

\section{References}

Alblas, A.A., Peters, K., Wortmann, J.C., 2014. Fuzzy sustainability incentives in new product development: an empirical exploration of sustainability challenges in manufacturing companies. Int. J. Oper. Prod. Manag. 34 (4), 513-545.

Alvarado-Quesada, I., Lars, H., Weikard, H., 2014. A review of existing schemes and an outline for a global. Biodivers. Conserv. 23 (1), 1-21.

Ammenberg, J., Sundin, E., 2005. Products in environmental management systems: drivers, barriers and experiences. J. Clean. Prod. 13 (4), 405-415.

Archer, N.P., Ghasemzadeh, F., 1999. An integrated framework for project portfolio selection. Int. J. Proj. Manag. 17 (4), 207-216.

Bitman, W.R., Sharif, N., 2008. A conceptual framework for ranking R\&D projects. IEEE Trans. Eng. Manag. 55 (2), 267-278.

Bocken, N.M.P., Farracho, M., Bosworth, R., Kemp, R., 2014. The front-end of ecoinnovation for eco-innovative small and medium sized companies. J. Eng. Technol. Manag. 31, 43-57.

Bocken, N.M.P., Allwood, J.M., Willey, A.R., King, J.M.H., 2011. Development of an eco-ideation tool to identify stepwise greenhouse gas emissions reduction options for consumer goods. J. Clean. Prod. 19 (12), 1279-1287.

Boks, C., 2006. The soft side of ecodesign. J. Clean. Prod. 14 (15), 1346-1356.

Borchardt, M., Wendt, M.H., Sellitto, M.A., Pereira, G.M., 2010. Reprojeto do contraforte: um caso de aplicação do ecodesign em manufatura calçadista. Production 20 (3), 392-403.

Bovea, M., Pérez-Belis, V., 2012. A taxonomy of ecodesign tools for integrating environmental requirements into the product design process. J. Clean. Prod. 20 (1), 61-71.

Bredillet, C., Tywoniak, S., Tootoonchy, M., 2017. Exploring the dynamics of project management office and portfolio management co-evolution: a routine lens. Int. J. Proj. Manag. 36 (1), 27-42.

British Standards Institution, 2006. BS 8887-1:2006 Design for manufacture, assembly, disassembly and end-of-life processing (MADE). In: General Concepts, Process and Requirements. BSI.

Brones, F., Carvalho, M.M., 2015. From 50 to 1: integrating literature toward a systemic ecodesign model. J. Clean. Prod. 96 (1), 44-47.

Brones, F., Carvalho, M.M., Zancul, E.S., 2014. Ecodesign in project management: a missing link for the integration of sustainability in product development? J. Clean. Prod. 80, 106-118.

Brook, J.W., Pagnanelli, F., 2014. Integrating sustainability into innovation project portfolio management - a strategic perspective. J. Eng. Technol. Manag. 34, 46-62.

Brownin, T.R., Yassine, A.A., 2016. Managing a portfolio of product development projects under resource constraints. Decis. Sci. J. 47 (2), 333-372.

Byggeth, S., Hochschorner, E., 2006. Handling trade-offs in ecodesign tools for sustainable product development and procurement. J. Clean. Prod. 14 (15), 1420-1430.

Carbonell, P., Rodriguez Escudero, A.I., 2016. The effects of decentralization in strategy-making and national culture on NPD portfolio planning. J. Prod. Innovat. Manag. 33 (S1), 101-116.

Carvalho, M.M., Rabechini, R., 2017. Can project sustainability management impact project success? An empirical study applying a contingent approach. Int. J. Proj. Manag. 35 (6), 1120-1132.

Chang, T.-R., Wang, C.-S., Wang, C.-C., 2013. A systematic approach for green design in modular product development. Int. J. Adv. Manuf. Technol. 68 (9-12), 2729-2741.

Cluzel, F., Yannou, B., Millet, D., Leroy, Y, 2016. Eco-ideation and eco-selection of R\&D projects portfolio in complex systems industries. J. Clean. Prod. 112, 4329-4343.

Collado Ruiz, D., OstadAhmad Ghorabi, H., 2013. Estimating environmental behavior without performing a life cycle assessment. J. Ind. Ecol. 17 (1), 31-42.

Cooper, R.G., Edgett, S.J., Kleinschmidt, E.J., 1999. New product portfolio management: practices and performance. J. Prod. Innovat. Manag. 16 (4), 333-351.

Dalhammar, C., 2016. Industry attitudes towards ecodesign standards for improved resource efficiency. J. Clean. Prod. 123 (June), 155-166.

Dangelico, R.M., 2017. What drives green product development and how do different antecedents affect market performance? A survey of Italian companies with eco-lables. Bus. Strat. Environ. 26 (8), 1144-1161.

Dangelico, R.M., Vocalelli, D., 2017. "Green Marketing”: an analysis of definitions, strategy steps, and tools through a systematic review of the literature. J. Clean. Prod. (in press).

Dekoninck, E.A., Domingo, L., O'Hare, J.A., Pigosso, D.C.A., Reyes, T., Troussier, N., 2016. Defining the challenges for ecodesign implementation in companies: development and consolidation of a framework. J. Clean. Prod. 135, 410-425.

Driessen, P.H., Hillebrand, B., Kok, R.A., Verhallen, T.M., 2013. Green new product development: the pivotal role of product greenness. IEEE Trans. Eng. Manag. 60 (2), 315-326.

Echeveste, M.E.S., Rozenfeld, H., Fettermann, D.D.C., 2017. Customizing practices based on the frequency of problems in new product development process. Concurr. Eng. 25 (3), 245-261.

Eppinger, S., 2011. The fundamental challenge of product design. J. Prod. Innovat. 
Manag. 28 (3), 399-400.

Fahimnia, B., Sarkis, J., Davarzani, H., 2015. Green supply chain management: a review and bibliometric analysis. Int. J. Prod. Econ. 162, 101-114.

Fiksel, J., 2012. Design for Environment: a Guide to a Sustainable Product Development, second ed. McGraw Hill, New York.

Goffin, K., 2012. Sustainability and new product development. In: Cranfield on Corporate Sustainability, pp. 105-118.

Gouvinhas, R.P., Reyes, T., Naveiro, R.M., Perry, N., Romeiro Filho, E., 2016. A proposed framework of sustainable self-evaluation maturity within companies: an exploratory study. Int. J. Interact. Des. Manuf. 10 (3), 319-327.

Hoejmose, S., Brammer, S., Millington, A., 2012. “Green” supply chain management: the role of trust and top management in B2B and B2C markets. Ind. Market. Manag. 41 (4), 609-620.

Hyung Jin Park, M., Lim, J.W., Birnbaum-More, P.H., 2009. The effect of multiknowledge individuals on performance in cross functional new product development teams. J. Prod. Innovat. Manag. 26 (1), 86-96.

Jabbour, C.J.C., Jugend, D., Jabbour, A.B.L.S., Govindan, K., Kannan, D., Leal, F.W., 2018. "There is no carnival without samba": revealing barriers hampering biodiversity-based R\&D and eco-design in Brazil. J. Environ. Manag. 206, 236-245.

Jabbour, C.J.C., Jugend, D., Jabbour, A.B.L.S., Gunasekaran, A., Latan, H., 2015. Green product development and performance of Brazilian firms: measuring the role of human and technical aspects. J. Clean. Prod. 87, 442-451.

Ji, P., Ma, X., Li, G., 2015. Developing green purchasing relationships for the manufacturing industry: an evolutionary game theory perspective. Int. J. Prod. Econ. 166, 155-162.

Johansson, G., 2002. Success factors for integration of ecodesign in product development: a review of state of the art. Environ. Manag. Health 13 (1), 98-107.

Jonas, D., 2010. Empowering projects managers: how management involvement impacts project portfolio management performance. Int. J. Proj. Manag. 28 (8), 818-831.

Jugend, D., Luiz, J.V.R., Jabbour, C.J.C., Silva, S.L., Lopes, A.B.L.S., Salgado, M.H., 2017. Green product development and product portfolio management: empirical evidence from an emerging economy. Bus. Strat. Environ. 26 (8), 1181-1195.

Jugend, D., Silva, S.L., 2014. Product-portfolio management: a framework based on methods, organization, and strategy. Concurr. Eng. 22 (1), 17-28.

Jugend, D., Silva, S.L., Salgado, M.H., Miguel, P.A.C., 2016. Product portfolio management and performance: evidence from a survey of innovative Brazilian companies. J. Bus. Res. 69 (11), 5095-5100.

Juntunen, J.K., Korsunova, A., Halme, M., 2016. Integrating stakeholders in product development-a set-theoretic study on sustainable innovations. Acad. Manag. Proc. 2016 (1), 15809.

Karlsson, R., Luttropp, C., 2006. EcoDesign: what's happening? An overview of the subject area of ecodesign and of the papers in this special issue. J. Clean. Prod. $14,1291-1298$.

Kester, L., Griffin, A., Hultink, E.J., Lauche, K., 2011. Exploring portfolio decisionmaking process. J. Prod. Innovat. Manag. 28 (5), 641-661.

Kester, L., Hultink, E.J., Griffin, A., 2014. An empirical investigation of the antecedents and outcomes of NPD portfolio success. J. Prod. Innovat. Manag. 31 (6), $1199-1213$.

Killen, C.P., 2017. Managing portfolio interdependencies: the effects of visual data representations on project portfolio decision making. Int. J. Manag. Proj. Bus. 10 (4), 856-879.

Knight, P., Jenkins, J.O., 2009. Adopting and applying eco-design techniques: a practitioners perspective. J. Clean. Prod. 17 (5), 549-558.

Kock, A., Heising, W., Gemünden, H.G., 2015. How ideation portfolio management influences front-end success. J. Prod. Innovat. Manag. 32 (4), 539-555.

Koga, T., Aoyama, K., 2008. Modular design method for sustainable life-cycle of product family considering future market changes. In: Proceedings of the ASME 2008 International Design Engineering Technical Conferences \& Computers and Information in Engineering Conference IDETC/CIE, pp. 3-6.

Kopmann, J., Kock, A., Killen, C.P., Gemünden, H.G., 2015. Business case control in project portfolios - an empirical investigation of performance consequences and moderating effects. IEEE Trans. Eng. Manag. 62 (4), 529-543.

Le Pochat, S., Bertoluci, G., Froelich, D., 2007. Integrating ecodesign by conducting changes in SMEs. J. Clean. Prod. 15 (7), 671-680.

Lerch, M., Spieth, S., 2013. Innovation project portfolio management: a qualitative analysis. IEEE Trans. Eng. Manag. 60 (1), 18-29.

Luchs, M.G., Brower, J., Chitturi, R., 2012. Product choice and the importance of aesthetic design given the emotion-laden tradeoff between sustainability and functional performance. J. Prod. Innovat. Manag. 29 (6), 903-916.

Luiz, J.V.R., Jugend, D., Jabbour, C.J.C., Luiz, O.R., Souza, F.B., 2016. Ecodesign field of research throughout the world: mapping the territory by using an evolutionary lens. Scientometrics 109 (1), 241-259.

Luttropp, C., Lagerstedt, J., 2006. Ecodesign and the ten golden rules: generic advice for merging environmental aspects into product development. J. Clean. Prod. 14 (15), 1396-1408.
Marcelino-Sádaba, S., González-Jaen, L.F., Pérez-Ezcurdia, A., 2015. Using project management as a way to sustainability. From a comprehensive review to a framework definition. J. Clean. Prod. 99, 1-16.

McNally, R.C., Durmusoglu, S.S., Calantone, R.J., Harmancioglu, N., 2009. Exploring new product portfolio management decisions: the role of managers' dispositional traits. Ind. Market. Manag. 38 (1), 127-143.

Moreira, N., de Santa-Eulalia, L.A., Aït-Kadi, D., Wood-Harper, T., Wang, Y., 2015. A conceptual framework to develop green textiles in the aeronautic completion industry: a case study in a large manufacturing company. J. Clean. Prod. 105 $371-388$.

Nyström, G., Wellander, R., 2016. Accessory Portfolio Planning at Axis Communications. Lund University.

Ölundh, G., Ritzén, S., 2004. Making an ecodesign choice in project portfolio selection. In: Engineering Management Conference, 2004. Proceedings. 2004, vol. 3. IEEE International, pp. 913-917.

Patterson, M.L., 2005. New product portfolio planning and management. In: Kahn, K.B. (Ed.), The PDMA Handbook of New Product Development, $2^{\mathrm{a}}$ ed pp. $46-58$.

Petala, E., Wever, R., Dutilh, C., Brezet, H., 2010. The role of new product development briefs in implementing sustainability: a case study. J. Eng. Technol. Manag. 27 (3), 172-182.

Perks, H., 2007. Inter-functional integration and industrial new product portfolio decision making: exploring and articulating the linkages. Creat. Innov. Mang. 16 (2), 152-164.

Pigosso, D.C., Rozenfeld, H., McAloone, T.C., 2013. Ecodesign maturity model: a management framework to support ecodesign implementation into manufacturing companies. J. Clean. Prod. 59, 160-173.

Pigosso, D.C., Zanette, E.T., Guelere Filho, A., Ometto, A.R., Rozenfeld, H., 2010 Ecodesign methods focused on remanufacturing. J. Clean. Prod. 18 (1), 21-31.

Prendeville, S., O'Connor, F., Palmer, L., 2014. Material selection for eco-innovation: SPICE model. J. Clean. Prod. 85, 31-40.

Primmer, E., Jokinen, P., Blicharska, M., Barton, D.N., Bugter, R., Potschin, M., 2015 Governance of ecosystem services: a framework for empirical analysis. Ecosyst. Serv. 16 (December), 158-166.

Rossi, M., Germani, M., Zamagni, A., 2016. Review of ecodesign methods and tools Barriers and strategies for an effective implementation in industrial companies. J. Clean. Prod. 129, 361-373.

Salem, M.A., Shawtari, F.A., Shawtari, F.A., Shamsudin, M.F., Shamsudin, M.F. Hussain, H.I., 2016. The relation between stakeholders' integration and environmental competitiveness. Soc. Responsib. J. 12 (4), 755-769.

Sauvé, S., Bernard, S., Sloan, P., 2016. Environmental sciences, sustainable development and circular economy: alternative concepts for trans-disciplinary research. Environ. Dev. 17, 48-56.

Schiederig, T., Tietze, F., Herstatt, C., 2016. Green innovation in technology and innovation management - an exploratory literature review. R\&D Manag. 42 (2), 180-192.

Sihvonen, S., Partanen, J., 2016. Implementing environmental considerations within product development practices: a survey on employees' perspectives. J. Clean. Prod. 125 (July), 189-203.

Silvius, A.G., Kampinga, M., Paniagua, S., Mooi, H., 2017. Considering sustainability in project management decision making; an investigation using Q-methodology. Int. J. Proj. Manag. 35 (6), 1133-1150.

Smith, A.D., Offodile, O.F., 2016. Green and sustainability corporate initiatives: a case study of goods and services design. Int. J. Process Manag. Benchmark. 6 (3) 273-299.

Simon, M., Poole, S., Sweatman, A., Evans, S., Bhamra, T., Mcaloone, T., 2000. Environmental priorities in strategic product development. Bus. Strat. Environ. 9 (6), 367.

Spieth, P., Lerch, M., 2014. Augmenting innovation project portfolio management performance: the mediating effect of management perception and satisfaction. R\&D Manag. 44 (5), 498-515.

Unger, B.N., Gemünden, H.G., Aubry, M., 2012. The three roles of a project portfolio management office: Their impact on portfolio management execution and success. Int. J. Project Manag. 30 (5), 608-620.

Verbano, C., Nosella, A., 2010. Addressing R\&D investment decisions: a cross analysis of R\&D Project selection methods. Eur. J. Innovat. Manag. 13 (3) 355-380.

Vercalsteren, A., 2001. Integrating the ecodesign concept in small and mediumsized enterprises, Experiences in the Flemish region of Belgium. Environ. Manag. Health 12 (4), 347-355.

Vezzoli, C., Ceschin, F., Diehl, J.C., Kohtala, C., 2012. Why have 'Sustainable ProductService Systems' not been widely implemented? Meeting new design challenges to achieve societal sustainability. J. Clean. Prod. 35, 288-290.

Vezzoli, C., Sciama, D., 2006. Life Cycle Design: from general methods to product type specific guidelines and checklists: a method adopted to develop a set of guidelines/checklist handbook for the eco-efficient design of NECTA vending machines. J. Clean. Prod. 14 (15), 1319-1325. 